dry specimen. In addition there is a black, highly chitinised structure at the base of each side piece; the structure is split into two curved branches, one of which is sharp pointed, the other rounded at the tip. The clasper is rather blunt-ended. The following material is before me:-Stoke Wood, Hereford (Wood); Boyton, Suffolk (Verrall); Llangollen ( $F . W . E$. $)$.

D. nubitipennis Curt.-According to Curtis this differ's from D. nebulosa in that "the 2 central black lines on the thorax are much longer, and the clouds on the wings are much less distinct." This reference to two black central lines would seem to exclude the last four species, and if Curtis's specimen was not a pale $D$. nebulosa, it must have been the species for which I now propose to use the name. I should have preferred to call it D. subnebulosa Strobl (described as a variety of D. maculata), had not Strobl stated that the central thoracic stripe was simple, as in the typical form. By colour characters this species falls with $D$. nebulosa, from which it is at once separated by the unmarked fork-cells. The hypopygial structure, however, would place it much nearer to $D$. maculata than to $D$. nebulosa. The ninth tergite is armed in the same way, and there is a short, thick, curved, black spine on the inner side of the side piece towards the base; in D. mubilipennis, however, this spine is simple instead of forked. I have taken the species commonly at Dartmouth, S. Devon, and Radwell, Herts; the National collection also contains examples from Sheviock and Torcross (Yerbury) and Ugbrooke (Verrall; determined as D. nebulosa).

D. nebulosa Mg.-This species needs no further elucidation, as it is readily separable from the others by the more elaborate clouding of the wings. The hypopygium resembles, without being identical with, that of $D$. dilatata. I have taken it at Waterford, Herts (abundantly), and Dartmouth, S. Devon, and there are various other specimens in the British Museum. It is no doubt common and widely spread.

British Museum (Nat. Hist.), London.

October 14th, 1920.

\title{
THE BRITISH SPECIES OF THE SYLVATICUS-GROUP OF PIPUNCULUS (DIPTERA
}

BY J. E. COLLIN, F.E.S.

A revision of the work on this genus published by the late Mr. Verrall in his "British Flies," vol. viii, has become necessary as the result of an examination of a considerable amount of material 
accumulated since 1901. This particularly applies to his Group V, in which he described only three species-geniculatus Mg., littoralis Beck., and sylvaticus Mg., while the present paper deals with seven. The whole genus is a difficult one, owing to the remarkable uniformity in structure throughout; while, in the case of the species of the above group, their small size adds to the difficulty of distinguishing the characters upon which the species are based, making the use of a microscope almost a necessity.

The group is distinguished by the renation-the discal cross-vein being at or about the middle of the discal cell, and the third costal segment very short, without a darkened stigma.

The British species may be tabulated as follows :-

\section{Males.}

1 (4) Eyes touching on the frons for a very short space. At least the front part of thorax conspicuously greyish when viewed from in front.

2 (3) All the thorax greyish. Abdominal hairs pale ....1. littoralis Beck.

3 (2) Only the front part of thorax greyish. Hairs on the humeri and front of thorax longer. Abdominal hairs dark.......2. minimus Beck.

4 (1) Eyes touching for a longer space on frons. Thorax not greyish when viewed from in front.

5 (6) Hind tarsi with a postero-dorsal ciliation of longish black hairs on at least the first two joints................. cilitarsis Strobl.

6 (5) Hind tarsi not ciliated.

7 (8) Hypopygium without a broad membranous depression, but with a somewhat diagonal groove or fold on the right. Only the last joint of (at least anterior) tarsi darkened. Hind trochanters armed with 3-4 distinct short bristles at base beneath .....4. sylvaticus $\mathrm{Mg}$.

8 (7) Hypopygium with a bruad membranous depression. Tarsi often darkened. Hind trochanters unarmed.

9 (10) Hind femora with an outstanding postero-ventral cilia of delicate palo hairs $\ldots \ldots \ldots \ldots \ldots \ldots \ldots \ldots \ldots . \ldots \ldots$. geniculatus $\mathrm{Mg}$.

10 (9) Hind femora with normal pubescence.

11 (12) Humeri yellow. Tarsi darkened. Hind trochanters with a slight rounded projection composed of dense soft pubescence. Abdominal sternites clothed with brown velvet-like pile ...6. nigritulus Zett.

12 (11) Humeri dark. Tarsi with only last joint darker. Hind coxae and abdominal sternites bare ............... flavitarsis, sp. n.

\section{Females.}

1 (2) Abdominal hairs pale .................. littoralis Beck.

2 (1) Abdominal hairs dark.

3 (6) Frons all dull, dusted greyish, even if only sparingly so on upper part.

4 (5) Frons all conspicuously dusted greyish. Aculeus perfectly straight. Ungues rather shorter ................. minimus Beck. 
5 (4) Frons sparingly dusted on upper half. Aculeus very long and slightly recurved. Ungues very long.............5. geniculatus Mg.

6 (3) Frons brightly shining to a greater or less extent in front of ocellar triangle.

7 (8) Ungues and pulvilli short as in the male.......6. nigritulus Zett.

8 (7) Ungues and pulvilli much longer than in the male.

9 (10) Humeri dark .................... f. flavitarsis, sp. n.

10 (9) Humeri yellow.

11 (12) Aculeus shorter than the basal part of hypopygium. Hind tibiae more conspicuously bent ..................... cilitarsis Strobl.

12 (11) Aculeus longer than basal part. Hind tibiae straighter

....4. sylvaticus $\mathrm{Ig}$.

In addition to the above, I possess a single female specimen captured by myself at Glenmore (Inverness) on June 5th, 1913, which appears to represent a distinct species. The frons is shining above, abdominal pubescence black, humeri yellow. Aculeus very long, reaching to end of first abdominal sternite, anterior femora and hind trochanters armed with tiny black spines beneath at the base; tarsi yellow, with the last joint black. It most resembles sylvaticus, but has a distinctly longer aculeus.

1. P. littoratis Becker is an easily distinguished species, sufficiently differentiated in Verrall's " British Flies." The hind trochanters, however, are armed with distinct, though small, dark bristles at the base beneath and not at the "end " as stated by Verrall, and these bristles are quite different from any tiny hairs which may be present on the anterior trochanters, though similar tiny bristles are present beneath the base of anterior femora in the female only.

Verrall ("British Flies," viii, 124) mentions a male from Bigot's Collection labelled "Alloneura flavipes," and a female from Kowarz's Collection separated off from sylvaticus, as belonging to littoralis Beck. This is incorrect: in these examples the abdominal pubescence is not so pale, the hind trochanters are unarmed, and the female has an entirely dusted frons, and an aculeus which is somewhat curved upwards as in vicinus Beck. or mutatus Beck.; in fact, both specimens must be near to vicimus, but the abdominal pubescence does not appear to be sufficiently conspicuous, and the triangular shape of the male hind trochanters is not marked.

2. P. minimus Becker. Berl. Ent. Zeitschr. xlii, 85 (1897), q.

o. Head much as in littoralis, the eyes touching for only a short space and the frons brilliantly silvery. Antennae darker, not so translucently yellowish towards tip. Disc of thorax not so dusted greyish, only the part in front of suture appearing distinctly greyish when viewed from in front. Abdomen less dusted, though inconspicuous greyish patches can be traced at the sides of segments; the tiny bristles darker (almost black). Hypopygium more projecting and with a more distinct diagonal suture above, widening out into a membranous 
depression. Legs with tarsi (especially the hind ones) distinctly darker and the knees only narrowly yellowish. Hind trochanters with only a hair or two in place of the short spines of littoralis.

ㅇ. Frons all dusted greyish (though the actual ocellar triangle is not very densely dusted), evenly concave about middle, and with a single linear central furrow ; whereas in littoralis the frons is considerably shining blackish on upper half, and there are two separated shallow furrows on at least the front part of this blackish half, while the dusted front half begins with a distinct prominence. Thorax and abdomen much as in the male. Aculeus longer in proportion to the basal part than in littoralis and perfectly straight, whereas in littoralis it is slightly recurved. Legs coloured as in the male, while the anterior femora bear tiny spines at the base beneath, which are much shorter and paler than in littoralis.

Length $2-2.5 \mathrm{~mm}$.

Described from three males and two females eaught by myself at Blakeney Point, Norfolk, on July 17th and 20th, 1920, where they occurred in company with littoralis among the Psamma growing on the sanddunes.

Becker described P. minimus in 1897 from a female in Loew's Collection, but later (1900), having captured other specimens in company with littoralis, came to the conclusion that minimus was only the female of littoralis. It is, however, quite certain that minimus of with an entirely dull frons cannot be the true female of littoralis, this latter being probably unknown to Becker. I therefore use the name minimus for the Blakeney specimens, in spite of the fact that there may be some doubt of their identity with the type, owing to the latter being described as having pale tarsi.

3. P. cititarsis Strobl. Mitt. Nat. Ver. Steiermark, xlvi, p. 113 (1909).

§. Closely resembling sylvaticus, but undoubtedly distinct. Thorax perhaps a little more shining. First abdominal segment not so dull. The abdominal pubescence short and scattered on the second to fourth segments, but longer and very distinct on the fifth, especially towards the hind-margin. Hypopygium as in sylvaticus, with a diagonal groove or fold beginning above on the right. Terminal lamellae of genitalia somewhat translucently yellowish, their tips lying in a semicircular excision in the hind-margin of the fourth ventral segment. Legs coloured as in sylvaticus, but the tarsi often obscured; hind tibiae more conspicuously bent and twisted, hind tarsi longer, the first two joints with a distinct ciliation of black hairs above or slightly postero-dorsally.

ㅇ. Resembling sylvaticus, but rather larger. Frons more widened out about middle and not shining for so long a distance at sides above. Abdominal pubescence hardly so long. Hypopygium with a rather longer basal part, and, in consequence, the aculeus shorter in proportion and rather more slender than in sylvaticus. Hind tibiae rather more bent and twisted. Tarsi rather 
brownish, hind tarsi with basal joints not ciliated, the other four joints with longish hairs above but hardly ciliated. Anterior femora with a pair of tiny black spines at the base beneath, and hind trochanters with 2-3 tiny bristles at base keneath, all very much as in sylvaticus.

Length fully $3 \mathrm{~mm}$.

Two males in the Verrall Collection (separated off from sylvaticus under the MS. name of pilitarsis) taken by Col. Yerbury at Brodie (Elgin) on August 7th, 1905. The same collector also captured another male at Nethy Bridge (Inverness) on July 28th, 1911. In the Cambridge University Museum there are five males and a female taken by Mr. F. Jenkinson at Logie (Elgin) in August 1903.

4. P. sylvaticus Mg. I have nothing to add to the description in "British Flies." The var.? mentioned by Verrall is my flavitarsis, and is at once distinguished by the bare hind trochanters.

5. P. geniculatus Mg. Verrall was undoubtedly wrong in considering his geniculatus as being the same as nigritulus. His P. geniculatus has obvious abdominal pubescence, though this is not so long on last segment as in sylvaticus and pititarsis. A distinguishing character in the male lies in the delicate ciliation of outstanding pale hairs on the postero-ventral surface of hind femora. The frons of the female is not brightly shining above; the aculeus reaches to the end of the first abdominal sternite; the anterior femora are armed beneath at the base with 1-2 small bristles, the hind trochanters may bear a few short hairs but not bristles, the tarsi are dark, and the ungues and pulvilli very large.

A further examination of Meigen's types will be necessary to decide whether his species was geniculatus of Verrall or the next species (nigritulus Zett.); this latter being unrecognised by Verrall at the time he examined these types.

\section{P. nigritulus Zett. Dipt. Scand. iii, 957 (1844).}

Resembling geniculatus ( $\mathrm{Mg}$.) Verr., but hind femora of male without the postero-ventral ciliation; anterior femora of female unarmed at the base beneath and all the ungues and pulvilli short as in the male.

§. Thoracic pubescence shorter than in geniculatus. The tiny abdominal bristles more numerous on 2nd-4th segments, but very little longer on the long fifth segment than elsewhere. Hypopygium smaller, the membranous depression large. A good distinguishing character lies in the dense velvety pile with which the 3 rd and 4 th abdominal sternites are clothed, these sternites being quite bare in geniculatus. Leg's with only the knees pale; hind trochanters unarmed, but apparently bluntly produced postero-ventrally, owing to the presence of a dense patch of pile. Hind femora with only the normal tiny hairs postero-ventrally. 
․ Upper two-thirds of frons and upper part of occiput shining black. Thorax and abdomen also rather more shining than in geniculatus. Hypopygium with a shorter, quite straight aculeus reaching only to the end of 2 nd abdominal sternite, whereas in geniculatus it is longer and slightly recurved. Legs with rather more slender femora, the anterior pairs unarmed at the base beneath; ungues and pulvilli short as in the male.

Length fully $3 \mathrm{~mm} ., \delta^{\circ}$; slightly smaller, 우.

I have examined the types in Zetterstedt's Collection at Lund, and they are undoubtedly the same as our British species, while Kowarz, and probably Becker, had correctly recognised the species. Verrall, subsequent to the publication of his vol. viii of " British Flies," had separated the females from geniculatus under the MS. name of gampsonyx, but failed to distinguish the males.

P. nigritulus cannot be called rare in Britain. Verrall had taken, but not distinguished from geniculatus, two males - one at Landport, near Lewes (Sussex), on July 4th, 1868, the other at Wimbledon (Surrey) on September 3rd, 1871 - and a female at Landport on June 6th, 1870. Col. Yerbury caught a female at Walton-on-Naze (Essex) on August 8th, 1907, and two females at Beachy Head (Sussex) on July 29th and 31st, 1914. Mr. F. Jenkinson has taken it at Crowborough (Sussex) in September, and in some numbers at Carrow, near Norwich (Norfolk), on June 6th and 7th, 1903. Mr. H. Scott found a female at Henley-onThames on July 17th, 1911, and Mr. C. G. Lamb has taken it at Wells (Somerset).

\section{P.flavitarsis, sp. n. ơ}

Resembling sylvaticus, but humeri darkened and hind trochanters unarmed.

ס. Third antennal joint not so rostrate as in sylvaticus, and with a tendency to be yellowish. Thorax slightly more shining and with dark humeri. Abdominal bristles less distinct (rather shorter and brownish-black) on last segment. Hypopygium with no groove above, but with a terminal wide depression. Legs with the first four joints of tarsi pale yellowish, hind trochanters unarmed, hind femora with a rather distinct postero-ventral ciliation of pale hairs, more distinct than in sylvaticus, but less so than in geniculatue. Radial vein more distinctly upcurved to costa, and fourth costal segment cousequently shorter.

9. Agreeing with the male. Frons snining for a short distance at vertex and very concave just beyond the shining part. Bristles on first abdominal segment yellowish. Anterior femora armed at base beneath with tiny yellowish bristles. Aculeus as in sylvaticus, but not quite so long.

Length about $2.5 \mathrm{~mm}$.

Described from a pair taken at Chippenham Fen (Cambs), the male on Sept. 13th, 1897, the female on Sept. 10th, 1897, while I also possess 
a pair taken by Mr. F. Jenkinson at Crowborough (Sussex) on June 30th, 1903. In the University Museum at Cambridge there are four males and a female taken in the New Forest (Hants) by Dr. Sharp and Mr. C. G. Lamb in June, July, and August; two females taken by Mr. F. Jenkinson at Crowborough (Sussex) on Sept. 6th, 1901, and June 29th, 1903 ; and a male taken by Mr. C. G. Lamb at Nethy Bridge (Inverness) in June 1907.

Newmarket.

October, 1920.

\section{DESCRIPTION OF A NEW SPECIES OF CRANE-FLY FROM NEW ZEALAND.}

BY G. V. HUDSON, F.E.S., F.N.Z.INST,

On August 18th, 1914, I discovered a single specimen of the large species of crane-fly briefly described below on the open hills to the south of Wellington. When a second specimen is available, I intend to send it to the British Museum (Natural History) for complete examination and description by a specialist; but, in the meantime, seeing the insect is a striking one and evidently very rare, the following provisional description will, I hope, suffice to ensure its recognition.

\section{Tipula nebulosa, n. sp.}

๑. Expanse of wings 2 inches. Length of body $\frac{5}{8}$ inch. General colour dull brown; there are two broad and two narrow longitudinal darker brown bands on the pronotum ; the prominent portions of the meso- and metanotum are also dark brown. The base of the abdomen is dull yellowish-brown, the remainder suffused with blackish-brown. Legs dark brown, darker towards the extremities. The wings are of full average width, grey, with numerous cloudy whitish blotches and spots, forming very irregular broken transverse bands; the first band is situated just beyond the basal cross-vein; the second, which is much the widest, beyond the middle of the wing immediately before the submarginal cells; the third band, which is very irregular and composed of numerous rather small spots, is situated on the apical and marginal areas. The halteres are long, pale yellowish-brown. The whole insect is covered with very fine pubescence.

The female is unknown, but being a winter species may possibly be semi-apterous.

Hiliview, Karori,

Wellington, New Zealand.

August 15th, 1920. 


\section{$2 \mathrm{BHL}$ Biodiversity Heritage Library}

Collin, J E. 1920. "The British species of the sylvaticus-group of Pipunculus (Diptera)." The Entomologist's monthly magazine 56, 270-276. https://doi.org/10.5962/bhl.part.15531.

View This Item Online: $\underline{\text { https://www.biodiversitylibrary.org/item/36034 }}$

DOI: https://doi.org/10.5962/bhl.part.15531

Permalink: https://www.biodiversitylibrary.org/partpdf/15531

\section{Holding Institution}

Smithsonian Libraries

\section{Sponsored by}

Smithsonian

\section{Copyright \& Reuse}

Copyright Status: NOT_IN_COPYRIGHT

This document was created from content at the Biodiversity Heritage Library, the world's largest open access digital library for biodiversity literature and archives. Visit BHL at https://www.biodiversitylibrary.org. 